\title{
Sarcoidosis and Corticosteroid Therapy: Dilemma from a Psychiatric Point of View
}

\author{
Mohd Amiruddin Mohd Kassim¹, Ruziana Masiran², Nicholas Pang ${ }^{1}$ \\ ${ }^{1}$ Faculty of Medicine and Health Sciences, Universiti Malaysia Sabah, Kota Kinabalu, \\ Malaysia, ${ }^{2}$ Department of Psychiatry, Faculty of Medicine and Health Sciences, Universiti \\ Putra Malaysia, Selangor, Malaysia
}

\begin{abstract}
Introduction and Methods: A man diagnosed with sarcoidosis developed partial retrograde amnesia followed by three months of depressive symptoms with panic attacks, which remitted with an antidepressant and a benzodiazepine. However, three months later hallucinations and overvalued persecutory ideations subsequently emerged, only to show partial response to antipsychotic treatment. Results: Sarcoidosis was treated with corticosteroids but serial thorax imaging shows minimal response. Corticosteroid was onboard throughout treatment, corresponding with non-remission of psychotic symptoms. There are persistent subjective cognitive difficulties but Mini Mental State Exam score is full. He is currently being treated with escitalopram, alprazolam and quetiapine. Conclusion: This case illustrated the dilemma between prolonging the corticosteroid therapy for sarcoidosis treatment and the psychiatric sequalae. While symptomatic antipsychotic treatment is effective, multi-disciplinary approach is imperative in determining the duration of the corticosteroid therapy.
\end{abstract}

Keywords: corticosteroid, sarcoidosis, psychosis, amnesia

Copyright $\odot 2021$ KBCSM, Zagreb

e-mail: alcoholism.kbcsm@gmail.com•www.http://apr.kbcsm.hr

\section{Introduction}

A 37-year-old risk management executive first presented to a private hospital in September 2016 with a three-month history of chest pain and axillary lymph node swelling. There was no mood, psychotic, neurotic or cognitive symptoms during those three months. There were multiple small palpable axillary lymph nodes roughly $1 \mathrm{x} 1 \mathrm{~cm}$ in size over the

Correspondence to:

Nicholas Pang, MD

Faculty of Medicine and Health Sciences,

Universiti Malaysia Sabah

Phone: +6016-8814058

E-mail: nicholas@ums.edu.my right axilla. Physical examination, including a full neurological examination, was otherwise unremarkable. The initial CT thorax in September 2016 was suggestive of sarcoidosis, with no lung involvement. An urgent histopathological examination in the same month showed non caseating granuloma. The patient was pulsed with IV methylprednisolone for 3 days and then started on oral prednisolone $60 \mathrm{mg}$ per day and maintained with same dose during the whole treatment course up to the time of current presentation.

On his second day of admission, corresponding to Day 2 of methylprednisolone, 
he abruptly developed retrograde amnesia to autobiographical memories and a large part of complex procedural skills. There was no anterograde amnesia. For the next three months, he also developed low mood with loss of interest, prominent hopelessness and worthlessness, disturbed sleep and appetite, with occasional suicidal thoughts. However, both brain MRI's carried out in September and October 2016 were normal, with no suggestion of neurosarcoidosis. He was started on oral escitalopram $15 \mathrm{mg} \mathrm{ON}$ and depressive symptoms gradually remitted. He also developed intermittent panic attacks beginning in November 2016, peaking at 3-4 times per week. Oral alprazolam $0.5 \mathrm{mg}$ BD was started and the panic attacks reduced to once to twice monthly on treatment.

Two months after his initial presentation, in December 2016, he started experiencing a mix of second and third-person auditory hallucinations and pseudo-hallucinations which were not mood-congruent. Depressive symptoms were in partial remission at that time. He also started developing mistrust towards others and fears of others harming him, which were not held to delusional intensity. There was no thought alienation, disorganised speech or behaviour, or any other delusions or hallucinations. Therefore, oral quetiapine was added subsequently for the hallucinations and titrated accordingly.

There is no previous medical or surgical history. There is no family history of mental illness, no new psychosocial stressors other than the illness itself, and no substance or alcohol use. He has been highly educated and was able to perform complex fiscal calculations and operate intricate computer software.
Mental state examination suggested a young-looking man with fair hygiene and good rapport. Speech was relevant and coherent. He was euthymic with appropriate affect, and there were no perceptual or thought disturbances. There were no objective cognitive abnormalities demonstrable.

A follow-up Mini Mental State Examination was performed in May 2018 and he scored perfectly. No other neurological investigations were performed in view of normal examination and radiology.

Steroid-induced mood, psychotic and neurocognitive disorders would be the provisional diagnosis. He fulfils full DSM-5 criteria for major depressive disorder, which included low mood, anhedonia, negative cognitions, sleep and appetite disturbances, as well as suicidal ideations. Panic attacks were also temporally associated with depressive symptoms and appear to have also responded to antidepressant treatment. However, his depressive disorder has a clear-cut temporal relationship to steroid initiation. As the patient was medically treated for sarcoidosis, he was subject to prolonged corticosteroid therapy, which may last up to 24 months. As the patient has consistently been on Prednisolone $60 \mathrm{mg}$ OD for prolonged duration, he was also at higher risk to develop psychosis, as evidenced by the auditory hallucinations. Apart from that, memory impairment has been associated with corticosteroid therapy, but the onset of the amnesia has been a peculiar one; he developed retrograde amnesia just after 1 day of corticosteroid pulse therapy, which is uncommon, as the usual onset would be after 4-5 days of therapy.

Differential diagnosis would include neurosarcoidosis with major depressive disorder. Albeit rare, it remains a possibility as the psy- 
chotic features and the subjective cognitive impairment appeared following the onset of symptoms of sarcoidosis. In addition, the two features were not associated with the onset and resolution of the depressive symptoms and were still present in conjunction with the current non-resolution of the organic cause. However, the points against neurosarcoidosis would be that there was no evidence on examination, imaging, and psychological testing to substantiate it.

Oral Escitalopram was titrated up to 15 mg daily, with oral quetiapine and alprazolam added subsequently for hallucinations and for panic attacks, respectively. The patient is currently being treated with oral escitalopram $15 \mathrm{mg}$ ON, quetiapine $100 \mathrm{mg}$ ON, alprazolam $0.5 \mathrm{mg}$ PRN and Prednisolone $60 \mathrm{mg}$ OD. So far there have been no focal neurological signs or symptoms. After treatment was commenced, there were no depressive symptoms. However, there are residual auditory hallucinations and the persecutory ideations still remain, but of a lesser intensity. In July 2017, six months after starting oral prednisolone, a thoracic CT showed minimal reduction in lymph node size. Hence, a video-assisted thoracoscopic surgery biopsy of the lymph nodes was performed in September 2017 with prednisolone continued alongside the antidepressant and anti-psychotic treatment (last known until September 2018). Subsequently the patient's psychotic symptoms significantly reduced. As a consequence, he has had to relearn many skills and subjectively feels slower at his work. He has had to re-learn driving, English and Malay language grammar, and how to operate computer software at work. However there has been no retrograde or anterograde amnesia following that date.

\section{Discussion}

Sarcoidosis is a systematic disease characterised histopathologically by non-caseating granulomas [1]. Its aetiology is as yet unknown; infectious, environmental, genetic, and immunologic postulations have all been considered [2]. At present there is no curative treatment for sarcoidosis. However, immunosuppressive and/or immunomodulatory drugs can be used to control the disease; with systemic corticosteroids remaining the firstchoice therapy in organ- and/or life-threatening sarcoidosis [3]. In a Cochrane review of corticosteroids for pulmonary sarcoidosis, treatment with oral steroids for 6 to 24 months improved thoracic radiograph findings, compared with placebo [4].

However, the prolonged duration of the corticosteroid therapy, although important, comes with multiple adverse effects. Cognitive deficits, particularly declarative memory deficits, have been well documented during both long- and short-term corticosteroid therapy. Deficits during short-term therapy are consistent with hippocampal dysfunction and occur with reversible atrophy of hippocampal neurons [5]. It is noted that new declarative memory deficiencies may emerge after just 4 to 5 days of dexamethasone or prednisone therapy, although in this case, retrograde amnesia became prominent after just one day of treatment [6].

At the same time, corticosteroids are known to cause mood disorders, as well as psychosis [7,8]. Although patients in early stage of treatment commonly present with mania, prevalence of depression is higher with long-term therapy, which is the case with the presented patient, even on low to moderate doses [7]. Psychosis, on the other hand, is known to occur in $1.3 \%$ of individu- 
als receiving prednisolone $40 \mathrm{mg}$ per day or less; $4 \%$ to $6 \%$ of patients receiving $41 \mathrm{mg}$ to $80 \mathrm{mg}$ per day; and $18.4 \%$ of patients receiving more than $80 \mathrm{mg}$ per day [8].

Despite that, the prognosis is excellent, with complete recovery in almost $90 \%$ of cases [9]. It is widely accepted that in the case of acute corticosteroid-induced psychiatric disturbances, atypical antipsychotics appear to yield the greatest benefit, with fewest adverse effects. While antidepressants have been found to help in some situations, they may exacerbate agitation and psychosis in others [10].

\section{Conclusion}

Corticosteroids are the mainstay of treatment for sarcoidosis and in certain cases, they can be protracted up to 24 months, based on disease progression. Despite its effectiveness, clinicians need to consider the risks, especially psychiatric, of prolonging the duration of the corticosteroid therapy. Although neuroleptics and mood stabilisers can be useful in managing psychiatric adverse effects, definitive treatment of this psychiatric issue is still the cessation of the triggering factor. A collective decision should be made between all stakeholders in order to determine a suitable and acceptable conclusion for solving this intricate dilemma.

\section{Acknowledgements}

None.

\section{Conflict of Interest}

The authors report no conflict of interest.

\section{References}

1. Young K, Simpson KP, Gilbert ER. Diaphragmatic Biopsies for the Diagnosis of Pulmonary Sarcoidosis. Am J Respir Crit Care Med. 2018;197:A1581.

2. Ahmadzai H, Huang S, Steinfort C, Markos J, Allen RK, Wakefield D, et al. Sarcoidosis: a state of the art review from the Thoracic Society of Australia and New Zealand. Medical J Aust. 2018;208:499-504.

3. Grutters JC, Van den Bosch JM. Corticosteroid treatment in sarcoidosis. Eur Respr J. 2006;28:62736.

4. Pietinalho A, Tukiainen P, Haahtela T, Persson T, Selroos O, Finnish Pulmonary Sarcoidosis Study Group. Early Treatment of stage II sarcoidosis improves 5-year pulmonary function. Chest. 2002;121:24-31.

5. Wolkowitz OM. Prospective controlled studies of the behavioral and biological effects of exogenous corticosteroids. Psychoneuroendocrinology. 1994;19:233-55.

6. Newcomer JW, Craft S, Hershey T, Askins, K, Bardgett ME. Glucocorticoid-induced impairment in declarative memory performance in adult humans. J Neurosci. 1994;14:2047-53.

7. Bolanos SH, Khan DA, Hanczyc M, Bauer MS, Dhanani N, Brown ES. Assessment of mood states in patients receiving long-term corticosteroid therapy and in controls with patient-rated and clinician-rated scales. Ann Allergy Asthma Immunol. 2004;92:500-5.

8. The Boston Collaborative Drug Surveillance Program. Acute adverse reactions to prednisone in relation to dosage. Clin Pharmacol Ther. 1972;13:694-8.

9. Lewis DA, Smith RE. Steroid-induced psychiatric syndromes: a report of 14 cases and a review of the literature. J Affective Disord. 1983;5:319-32.

10. Warrington TP, Bostwick JM. Psychiatric adverse effects of corticosteroids. Mayo Clin Proc. 2006;81:1361-7. 


\section{Sarkoidoza i terapija kortikosteroidima: dilema iz psihijatrijske perspektive}

Sažetak- Uvod i metode: Pacijent kojemu je postavljena dijagnoza sarkoidoze razvio je djelomičnu retrogradnu amneziju, praćenu tromjesečnim simptomima depresije s napadima panike, koji su se povukli na liječenje antidepresivom i benzodiazepinom. Međutim, tri mjeseca kasnije pojavile su se halucinacije te persekutorne ideje koje su pokazale svega parcijalni odgovor na liječenje antipsihoticima. Rezultati: Unatoč liječenju sarkoidoze kortikosteroidima, serijsko snimanje toraksa pokazalo je minimalan odgovor. Tijekom cijelog liječenja korišteni su kortikosteroidi, što korelira sa psihotičnim simptoma koji se povlačili. Perzistiraju trajne subjektivne kognitivne poteškoće, ali rezultat Mini Mental State Exam je pun. Trenutno se liječi escitalopramom, alprazolamom i kvetiapinom. Zaključak: Ovaj slučaj ilustrira dilemu između produljenog liječenja sarkoidoze kortikosteroidima te psihijatrijskih sekvela. lako je simptomatsko liječenje antipsihoticima učinkovito, multidisciplinarni pristup je nužan u određivanju trajanja terapije kortikosteroidima.

Ključne riječi: kortikosteroid, sarkoidoza, psihoza, amnezija 
